\title{
THE ALBEDO OF SEA-ICE AND ICE ISLANDS IN THE ARCTIC OCEAN BASIN
}

\author{
Kirby J. Hanson
}

\section{Introduction}

$\mathbf{T}$ He surface albedo* and its change during the spring, summer and autumn seasons is probably the most significant regional factor affecting the heat budget of the Arctic Ocean basin. In the spring, when most of the sea-ice is covered with snow, the albedo of the surface is between 80 and 90 per cent. In mid-summer, however, the snow cover melts, fairly large puddles begin to appear on the sea-ice and the albedo becomes smaller. In addition the total ice cover is reduced from nearly 10 -tenths in the spring to about 8-tenths in the summer, which lowers the albedo still further.

For studies of the surface and atmospheric heat budget of the Arctic Ocean basin, it is important to determine representative albedo values for various characteristic surfaces. The work reported here is one of the first attempts to determine the albedo of various ice conditions in the Arctic by aircraft.

\section{Albedo determination}

\section{Airborne albedo measurements}

During the summer of 1958, the Applied Oceanography Branch of the U. S. Navy Hydrographic Office obtained airborne radiation measurements over parts of the Beaufort and Chukchi seas. Flights were made by Patrol Squadron 9 in P2V aircraft based at Eielson AFB, Alaska; generally, they were flown along three predetermined tracks extending to $77^{\circ} \mathrm{N}$. or about 300 nautical miles north of the Alaskan coast. In addition to the solar radiation measurements, photographic and visual ice-reconnaissance observations were made during the flights. Flight altitudes ranged from 200 to 2,000 feet and about one-half of the observations were made at an altitude of 500 feet. It is assumed that the effect of atmospheric scattering is negligible (Robinson 1958) and no altitude corrections have been applied to the values.

The airborne radiation measurements were made with two Eppley 50-junction horizontal-incidence pyranometers with a Leeds and Northrup Speedomax-H recording potentiometer. One pyranometer was mounted

*Ratio of the amount of total solar radiation reflected by a surface to the amount incident upon it, expressed in per cent. 
facing downwards in the after-hatch of the P2V with its sensing element at the same level as the lower surface of the aircraft. Periodic checks by an observer showed that no engine oil or other film reached the glass envelope of the pyranometer. The other pyranometer was mounted facing upwards inside the navigator's astrodome, on a solid mount without provision for levelling the instrument. This created two sources of error: (a), the absorption of solar radiation by the plexiglass astrodome and (b), the lack of correct levelling of the instrument - a factor that is extremely important in polar regions (Fritz 1958). To resolve the first difficulty a transmission factor was determined using a spectral transmittance curve of the plexiglass and a spectral-energy-distribution curve for solar radiation. The transmission factor was used to correct observations obtained beneath the plexiglass astrodome. The problem of instrument levelling was resolved by accepting only those observations made when the sky was cloudy above the aircraft, thereby using only observations in which the incident solar radiation was diffuse. The results of this study are therefore not applicable to clear-sky conditions in the Arctic. With clear skies, specular reflection from the ice and water surface tends to increase the albedo slightly.

Table 1. Summary of airborne albedo measurements obtained over the Arctic Ocean north of the Alaskan coast during July and August 1958.

Surface ice cover

Albedo-per cent

$\begin{array}{lr}\text { Open water } & 4 \\ 0.1-0.4 & 15 \\ 0.5-0.7 & 22 \\ 0.8-0.9 & 40\end{array}$

For the period July 14-August 20, 1958, 150 albedo observations were evaluated. The albedo values were tabulated together with corresponding ice-cover observations from U. S. Navy Hydrographic Office 10-day mean ice-cover charts (USNHO TR66). The albedo observations were grouped by ice-cover classes and average albedo values were computed for the classes. The results are shown in Table 1 . The average albedo of ice-free water was 4 per cent (based on 55 observations) with a standard deviation of 2 per cent. For the 8- to 9-tenths ice-cover class, the average albedo was 40 per cent ( 56 observations) with a standard deviation of 13 per cent. The large standard deviation results from a difference in resolution of these two variables. The Eppley pyranometer responds to about 99 per cent of the incident radiation in one-half minute (Dogniaux 1955). As the aircraft traveled about 4 miles per minute, the pyranometer saw vertically each minute an integrated area less than 2 miles in length. Neither daily nor 10-day mean ice-cover charts can provide a resolution of this magnitude. 


\section{Surface albedo measurements}

The entire Arctic Ocean basin undergoes a large seasonal change of albedo, with minimum albedo values during the melt period. The reason for this coincidence of minimum albedo and summer melt is that large amounts of melt water collect on the relatively flat floes and effectively reduce the albedo.

Table 2. Albedo measurements on ice island T-3, July-October 1957.

\begin{tabular}{|c|c|c|c|}
\hline \multirow[b]{2}{*}{ Date } & \multicolumn{3}{|c|}{ Albedo of } \\
\hline & $\begin{array}{c}\text { snow } \\
\text { per cent }\end{array}$ & $\begin{array}{c}\text { melting ice } \\
\text { per cent }\end{array}$ & $\begin{array}{l}\text { melt-water pools } \\
\text { per cent }\end{array}$ \\
\hline July 17 & - & 78 & 39 (1-2 ft. deep) \\
\hline August 1 & 一 & 76 & 38 (1-2 ft. deep) \\
\hline September 17 & 81 & - & - \\
\hline October 8 & 78 & - & - \\
\hline
\end{tabular}

To determine the albedo of natural polar surfaces, Murray (pers. com.) obtained measurements on Ice Island T-3 during 1957 (Table 2). His values for the melt period of July and August 1957 indicate that the albedo of melt-water pools (1-2 feet deep) is one-half that of the ice ridges between the pools. In order to get representative albedo values, he used portable measuring equipment a number of miles from camp, well away from camp contamination. Measurements over camp-contaminated ice in July 1958 gave albedo values of only 42 per cent and during the following year measurements again indicated an albedo of 42 per cent during July and 49 per cent during August - values that are only about one-half those obtained by Murray. With other things being equal, the lower albedos would cause about twice the amount of melting in the camp area as compared with the remainder of $\mathrm{T}-3$ as has been actually shown by observations during the past few years (Smith, pers. com.)

The surface of T-3, as seen in Fig. 1, consists of quasi-parallel ridges and troughs; during the summer melt water forms elongated lakes in these troughs. Concerning the origin of these surface features, Hattersley-Smith (1957) says that wind action is the most likely cause of the rolls (ridge and trough systems) on the Ellesmere Ice Shelf as wind-driven water is an effective means of ablating ice. Crary (1960) has suggested that a lower albedo over these lakes, together with wind action to aid convection, accounts for differential surface ablation that in turn creates the ridge and trough systems. As the maximum depth of these T-3 lakes is about 4-5 feet (Crary 1960), Murray's albedo values suggest that about twice as much solar energy is absorbed by the lake bottoms than by the ice ridges between 


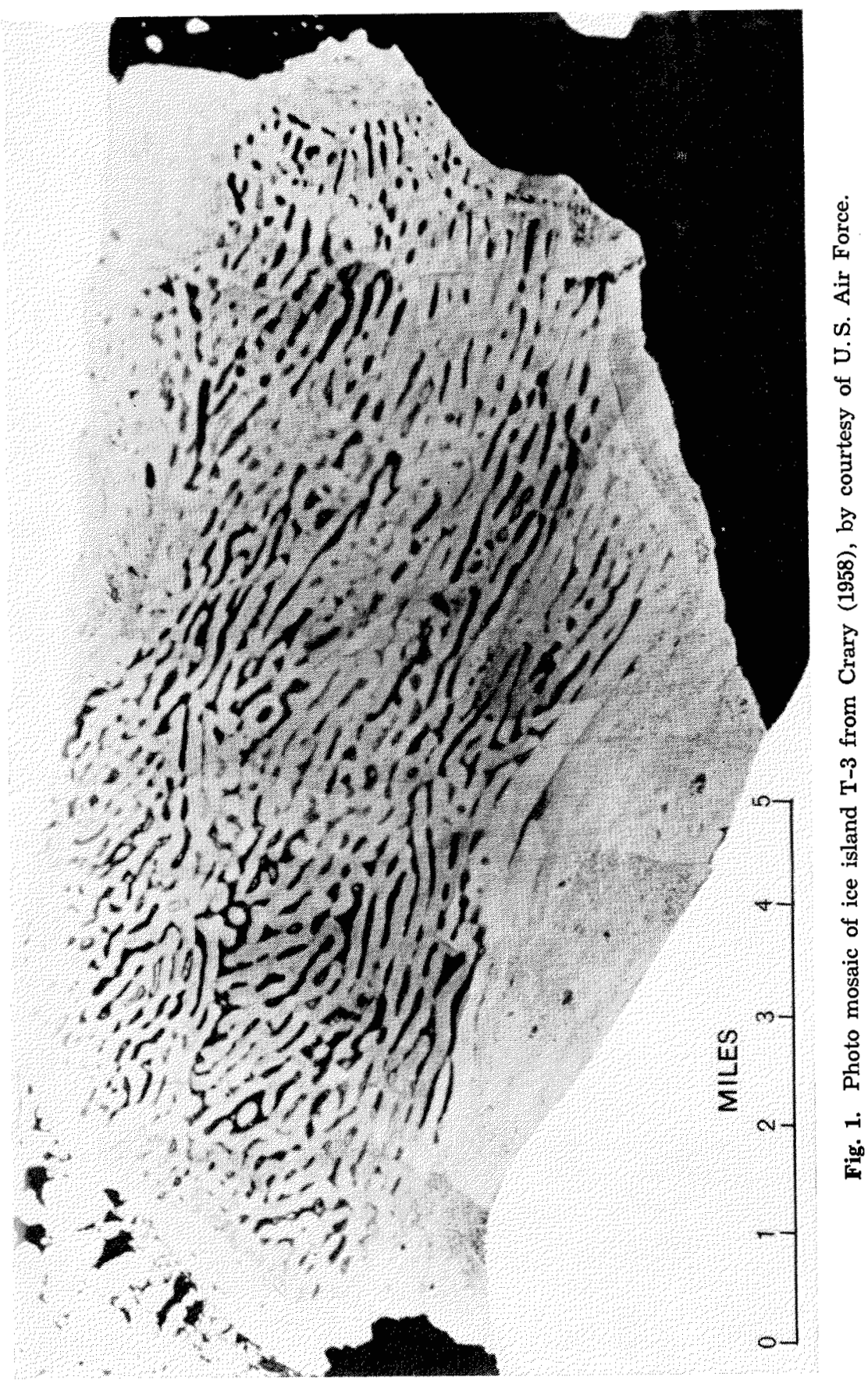


the lakes; this would cause twice the amount of ablation under the meltwater lakes as on the ridges.

Solar radiation measurements at Soviet Drifting Stations NP-4 and NP-6 in 1956 and 1957 (Briazgin 1959) indicate that the albedo of melting sea-ice averages 60 per cent and the albedo of melt-water pools 1-4 feet deep averages 20-22 per cent. This would cause about three times the amount of ablation under melt-water pools as on the non-water covered sea-ice. At the U. S. Drifting Station A, Untersteiner (1961) found that the average albedo of clean, melting sea-ice with a disintegrating surface lies between 62 and 70 per cent; also, he noted that the amount of ablation below melt-water pools was twice the amount for "dry" surfaces during the summer of 1957 and more than 3 times the amount during the summer of 1958 .

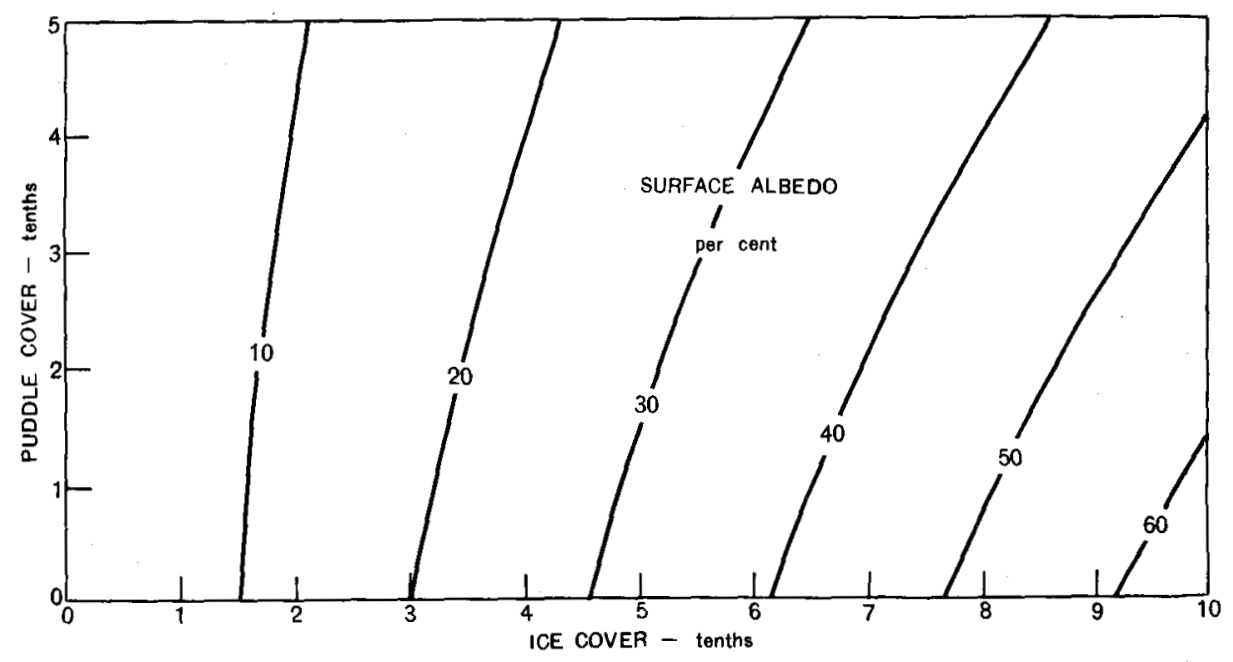

Fig. 2. Surface albedo versus ice and puddle cover.

\section{Albedo vs. ice and puddle cover}

It is possible to show the most probable relation between ice cover, puddle cover, and surface albedo by assuming the following: (a) the average albedo of 8.5-tenths ice cover is 40 per cent; (b) this ice is 5-tenths covered with pools of melt water; (c) the difference between the albedo of pools and ice is 38 per cent.

$$
\mathrm{A}=\mathrm{I}(65-3.8 \mathrm{P}) / 10
$$

Where: $\mathrm{A}=$ the albedo, expressed in per cent,

$I=$ the fraction of total area covered with ice, expressed in tenths, and

$\mathrm{P}=$ the fraction of ice covered with puddles, expressed in tenths. 
This equation shows that if the ocean were completely covered with melting sea ice, the albedo could range from 65 to 46 per cent as the proportion of puddles ranged from zero to 5 -tenths (assumed maximum value). The albedo values corresponding to all possible ice and puddle cover values are shown in Fig. 2.
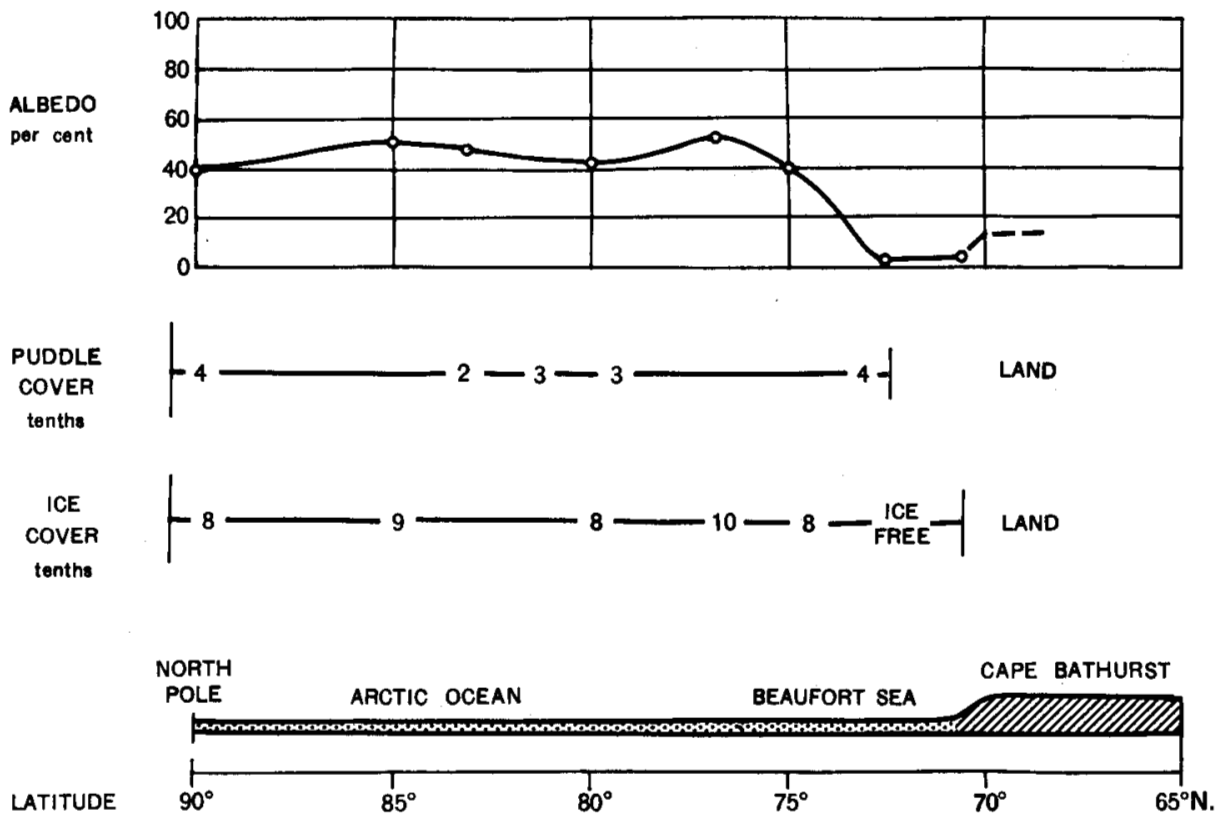

Fig. 3. Surface albedo, ice and puddle cover along a line from Cape Bathurst, N.W.T., Canada, to the North Pole, based on ice and puddle cover observations in July and August 1948 and albedo observations in July and August 1958.

\section{Meridional variation of albedo}

The 375th Weather Reconnaissance Squadron USAF, in collaboration with the U. S. Navy Hydrographic Office, conducted a study in 1948 to determine the gross features of the ice pack between Alaska and the North Pole. Both visual and photographic observations of the ice were made on weather reconnaissance ("Ptarmigan") flights from Fairbanks, Alaska past Prince Patrick Island to the North Pole and return. The data were summarized and published by the Hydrographic Office (USNHO 1949) as a preliminary study of the features of sea-ice in the Arctic Ocean. Fig. 3 is prepared from these data and shows, in a section from the North Pole to Cape Bathurst, N. W. T., Canada, the gross features of ice and puddle cover during the melt season of 1948. Also shown are the albedo values that were calculated with Equation (1) to correspond with the ice and 
puddle cover observations. The albedo of open water is 4 per cent from Cape Bathurst to the beginning of the pack ice near $72^{\circ} \mathrm{N}$. From that point the albedo increases rapidly to a maximum of 52 per cent near $77^{\circ} \mathrm{N}$. due to a greater concentration of small and medium floes. Another maximum of 52 per cent is found near $85^{\circ} \mathrm{N}$. where a minimum of puddle cover (2-tenths) was observed. The albedo in the vicinity of the Pole itself was 40 per cent.

If only the gross features of the surface along the section from the Pole to $72^{\circ} \mathrm{N}$. (Fig. 3) are considered, the albedo ranges from 40 to 52 per cent. If an average ice cover of 8.5-tenths and puddle cover of 3-tenths is assumed, the average albedo along this section is 46 per cent. Sverdrup (1933) has estimated that the albedo of the Arctic Ocean during summer melt conditions is between 60 and 65 per cent. It should be remembered that the standard deviation of the airborne measurements is quite large; therefore, on the basis of these measurements it cannot be stated that Sverdrup's figure is incorrect. In addition, Schwarzacher (1959) has shown that the summer ablation can vary greatly from year to year; the floe on which U. S. Drifting Station A was located had almost no ablation in 1951, whereas nearly 1 metre of ice was lost in 1955. As ice thickness, ablation, and puddle cover from which Sverdrup derived his higher albedo may have been quite different in the vicinity of the Maud in 1923, the lack of agreement is understandable.

\section{Ice island}

\section{Arctic heat budget and ablation}

In examining the surface heat budget of T-3 for the summer of 1953 , Fritz (1958) points out difficulties in reconciling heat budget calculations with surface ablation observations if an albedo of 75 per cent is assumed. Much of the solar radiation penetrates the ice surface causing internal melting rather than ablation of the ice surface (Untersteiner 1961). Therefore, heat budget calculations and surface ablation observations need not necessarily agree and the albedo value of 75 per cent for Ice Island T-3 may not necessarily be incorrect.

\section{Sea-ice}

With regard to surface ablation, only the albedo of the ice floes themselves is of interest. The relation in equation (1) shows that the average albedo of the floes (no open water) with 3-tenths puddle cover is 54 per cent along the section from Cape Bathurst to the Pole. This value has a possible significance in Arctic heat budget calculations.

Using an albedo of 66 per cent for pond-free ice, Untersteiner (1961) determined a net radiation of $+134 \mathrm{cal} . \mathrm{cm}^{-2}$ day $^{-1}$ for maximum melting conditions in the Arctic. Assuming an albedo of 60 per cent as representative for melting sea-ice, the author (1961) determined that during July the net radiation of sea-ice averages about $+135 \mathrm{cal} . \mathrm{cm} \cdot .^{-2}$ day $^{-1}$. A comparison of the radiation fluxes is given in Table 3 . The reason for the close 
agreement between net radiation values calculated using these differing albedos is that resulting differences in net solar radiation are compensated by differences in the net terrestrial radiation.

Table 3. Comparison of arctic ice floe radiation budgets.

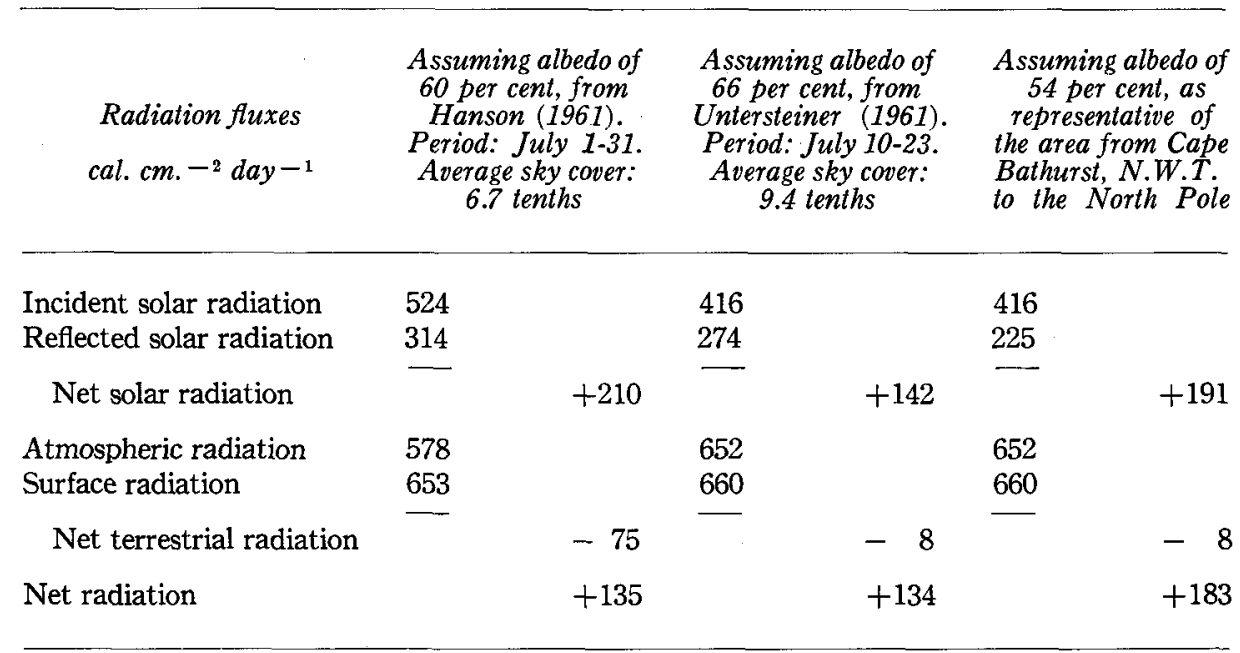

In discussing components of the arctic heat budget, Untersteiner (1961) has shown that during melting conditions the sensible and latent heat fluxes at the surface are about an order of magnitude smaller than the net radiation. Also, a small gain of sensible heat $\left(+9 \mathrm{cal} . \mathrm{cm} \cdot{ }^{-2}\right.$ day $\left.^{-1}\right)$ is compensated by a small loss of latent heat $\left(-11 \mathrm{cal} . \mathrm{cm}^{-2}\right.$ day $\left.^{-1}\right)$. As a result, most of the net radiation is available for surface ablation, heating and internal melting of the ice. Untersteiner found that during a 14-day period of July 1957, 62 per cent of this energy was realized as surface ablation and 38 per cent as internal heating and melting.

If an albedo of 54 per cent, as determined from the Cape Bathurst-Pole section, is applied to Untersteiner's values, as shown in Table 3, the net radiation for maximum melt conditions would be $+183 \mathrm{cal} . \mathrm{cm} .^{-2}$ day $^{-1}$. If the same meteorological conditions continued during the month of July, the energy available at the surface would total about $5670 \mathrm{cal} . \mathrm{cm} .^{-2}$ and it is reasonable to expect there would be a total surface ablation of nearly 50 $\mathrm{cm}$. during the month and about $2100 \mathrm{cal} . \mathrm{cm} .^{-2}$ would be used for internal warming and melting of the ice.

\section{Concluding remarks}

The albedo information in this study suggests that the albedo of melting shelf-ice (not including puddles) is about 77 per cent whereas the albedo of melting sea-ice (not including puddles) is about 65 per cent. This indicates that under similar conditions the ablation of sea-ice is greater than 
the ablation of shelf-ice by a factor of 1.5. Unfortunately, this cannot be confirmed by past observations as ice floe and ice island data have been gathered over widely scattered parts of the Arctic Ocean under differing radiation conditions. However, the measurements that are available indicate that the average ice island and ice floe ablation is about the same (Crary 1960, Schwarzacher 1959), although the amount of summer ablation may vary from year to year.

\section{References}

Briazgin, N. N., 1959. The problem of the albedo on the surface of drifting ice. Probl. Arkt. i Antarkt. No. 1:33-39 [Translated for Geophysics Research Directorate, Air Force Research Division by Am. Meteor. Soc. on contract AF 19(604)6113].

Crary, A. 1958. Arctic ice island and ice shelf studies. Part I, Arctic 11:3-42.

Crary, A. 1960. Arctic ice island and ice shelf studies. Part II, Arctic 13:32-50.

Dogniaux, R., and R. Rastiels. 1955. Techniques modernes de mesure de l'éclairement énergétique solaire. Inst. Roy. Met. Belg., Publ. B. No. 16:1-47.

Fritz, S., 1958. Solar radiation measurements in the Arctic Ocean. Polar Atmosphere Symposium, Part I, Meteorology. AGARDograph No. 29:159-66.

Hanson, K. J., 1961. Some aspects of the thermal energy exchange on the south polar snowfield and arctic ice pack. Monthly Weather Review. 89:173-7.

Hattersley-Smith, G., 1957. The rolls on the Ellesmere ice shelf. Arctic 10:32-44.

Robinson, G., 1958. Some observations from aircraft of surface albedo and the albedo and absorption of clouds. Archiv für Meteorologie, Geophysik und Bioklimatologie, Serie B, 9:28-41.

Schwarzacher, W., 1959. Pack ice studies in the Arctic Ocean. J. Geophys. Res. 64:2357-67.

Sverdrup, H. U. 1933. Meteorology. Part I, Discussion. The Norwegian North Polar Expedition with the "Maud". 1918-25. Scientific Results, Vol. II:108. Bergen: Geofysiks Institutt.

Untersteiner, N., 1961. On the mass and heat budget of arctic sea ice. Archiv für Meteorologie, Geophysik und Bioklimatologie, Serie A, 2:151-82.

U. S. Navy Hydrographic Office Technical Report No. 66. 1959. Report of the ice observing and forecasting program, 1958.

U. S. Navy Hydrographic Office. 1949. Preliminary study of the features of sea ice in the Arctic Ocean between April and September 1948. 